\title{
Iron, manganese, cadmium, chromium, zinc and arsenic groundwater contents of Agbor and Owa communities of Nigeria
}

\author{
Hector Henry Oyem ${ }^{1,2^{*}}$, Ifeanyi Mirian Oyem ${ }^{1,3}$ and Amii Isaac Usese ${ }^{4}$
}

\begin{abstract}
Iron, manganese, zinc, cadmium, and chromium heavy metals and arsenic contents of groundwater in area and surrounding environment, of Ika land in the Delta state, Nigeria was studied. Groundwater without any treatment is the predominant source of drinking water by inhabitants of these communities. However, the quality of this water source is not immediately known, raising questions of its safety.

Results of a regional composite of groundwater obtained, shows high iron (27\%) and zinc (36\%) contents in Boji-Boji Agbor area, manganese (31\%) was highest in Boji-Boji Owa. Alihame recorded the lowest value of zinc (8\%), while manganese was lowest in Agbor Obi area (12\%). Arsenic, cadmium, and chromium were below detection limit in all the sample sites. Correlational matrix analysis revealed no significant relationships between metal types studied. Analyses of chronic daily dose intake (CDI), and hazard index were all very low. A hazard index of 0.01 was obtained. One-way ANOVA show significant statistical difference in the mean concentrations of the heavy metals for the different sample sites, which indicate that different sites contribute differently to the mean concentrations of the groundwater in the study area.

Four conclusions are drawn from this study. Indications are that the heavy metals present in the Nigerian aquifer are very much below the maximum concentration levels and guideline values of national and WHO standards. Secondly, there is a heavier load of these metals in the city centre than in the suburbs; with Boji-Boji area Agbor/Owa urban areas accounting for 27 and 20 percent of load respectively. Thirdly, the below detection limit results for some of the metal ions and the very low concentrations of those detected are pointers to the absence of industrial activities and mining. Finally, the groundwater in the study area is considered to be generally safe with respect to the contaminants studied and results posted for the composite samples. Inhabitants are therefore under no illusion of immediate or remote health challenges with regards to the heavy metals analyzed. More individual sampling, however, is recommended.
\end{abstract}

Keywords: Ground water; Boji-Boji area; Heavy metals; Chronic daily intake; Hazard Index; Guideline value

\section{Background}

Water is a precious and most commonly used resource (Ramesh and Elango 2014). It is one of the most abundant chemical substances on earth, and covers two thirds of the earth's surface (Ramesh and Elango 2014). According to Bresline (2007) and National Academy of Science NAS (2009), over one billion people lack access to clean safe water. The available freshwater to man is

\footnotetext{
* Correspondence: hectoroyem@yahoo.co.uk

'Department of Integrated Science, College of Education, Agbor, PMB 2090, Delta State, Nigeria

${ }^{2}$ School of Chemistry, Newcastle University, Newcastle, NE1 7RU, United Kingdom Full list of author information is available at the end of the article
}

hardly $0.3-0.5 \%$ of the total water available on the earth and its judicious use is imperative (Ganesh and Hedge 1995). Many people in the world especially majority of which live in rural areas among the poorest and most vulnerable do not have access to safe clean drinking water (MacDonald and Calow 2009). In a recent survey by Majuru et al. (2011) an estimated 65 million Nigerians had no access to safe water. Provision of clean, reliable and portable water in rural areas and urban slums remains a challenge to governments throughout the world especially considering the fact that larger percentage of the population live in the urban areas (Ahaneku and Adeoye 2014). Without clean water, 
people's health and livelihoods can be severely affected (MacDonald and Calow 2009).

The burden of providing water close to consumers is met by boreholes that tap groundwater. These boreholes are typically deep (more than $100 \mathrm{~m}$ ), narrow, mechanically-drilled wells fitted with electric pumps to tap groundwater reservoirs.

Groundwater is a vital hidden natural resource (Tularam and Krishna 2009; Lashkaripour and Ghafoori 2011). Groundwater can be found in most environments and generally requires no prior treatment and can be found close to the points of demand often at low cost (MacDonald and Calow 2009). Traditionally regarded as being of good natural quality mostly from its geological environment, this does not mean that natural groundwater is always of good quality (MacDonald and Calow 2009). Water in its natural state may not be pure since it is a universal solvent with the ability to dissolve numerous chemicals and thus carry a lot of impurities that can be injurious to health if it exceeds tolerable limits World Health Organization WHO 1984. Consequently the, groundwater resource itself is not invulnerable given the ability to pump out large quantities of water and the advent of particularly persistent contaminants (MacDonald and Calow 2009). The natural quality can vary from one rock type to another and also within aquifers along its flow paths. There is also the possibility for chemical reactions between the water and rock material through which it flows depending on the flow path (Lashkaripour and Ghafoori 2011), especially since groundwater movement is slow (MacDonald and Calow 2009). Groundwater quality can deteriorate through contamination of the local groundwater, or direct contamination of the water supply itself (MacDonald and Calow 2009). Contaminants can migrate vertically to the aquifer and then to the borehole, or more dangerously, horizontally through permeable soils to poorly constructed supplies (MacDonald and Calow 2009).

Consistent from findings reported in literature is that groundwater is polluted from physical processes and anthropogenic activities (Idoko 2010). Among the chemical contaminants of groundwater are some heavy metals. Drinking groundwater and surface water contaminated by heavy metal ions is detrimental to health (Ohwoghere 2012). Metallic contaminants are serious concerns in many water bodies around the world United Nations Environmental Programme Global Environmental Monitoring System, (United Nations Environmental Programme Global Environmental Monitoring System and UNEP 2007). Many potentially deadly diseases associated with groundwater consumption have been traced to heavy metal contaminants. Interestingly though, some of these same metals are required by the body in trace quantities.
However, large doses especially over the course of time are inimical to health.

Water is essential for life but it does transmit diseases in countries in all continents - from the poorest to the wealthiest (World Health Organization WHO 2010). Millions of people are exposed to unsafe levels of chemical contaminants in their drinking water (World Health Organization WHO 2010). Monitoring metals in surface or groundwater supplies provides background information needed to determine the suitability of water resources for human consumption (United Nations Environmental Programme Global Environmental Monitoring System and UNEP 2007).

In Boji-Boji area of Agbor/Owa communities in Delta State Nigeria, groundwater is the dominant source of water for the people. This resource is flagrantly consumed without recourse to its quality. We are not immediately aware of any previous study on the groundwater quality of this area. It is imperative to understand the groundwater resources to ensure it is fit to drink and to protect the water supply from contamination (MacDonald and Calow 2009). Urgent need for water prioritizes borehole development over scientific study of groundwater quality. The continued consumption of untreated and possibly contaminated groundwater should be expected to pose short or long term (or even both) health implications to the people.

The drinking water guidelines applied in this study are the Nigerian Industrial Standard (NIS), World Health Organization (WHO), United States Environmental Protection Agency (USEPA), and the European Union $(E U)$ as presented in Table 1. However, emphasis is on the Nigerian and WHO guideline values presented in Table 1.

Human and natural factors have been noted as making it difficult for these guideline values to be maintained generally (United Nations Department of Economics and Social Affairs and UNDESA 2001).

In this exercise, we study some heavy metal characteristics in the groundwater from boreholes in Boji-Boji Agbor/Owa town and its immediate suburbs of Alihame and Owa Alero communities with the intention of evaluating its quality.

\section{Study area}

The study area (Agbor/Owa town commonly referred to as Boji-Boji) found within longitudes $6^{\circ}-6^{\circ} 30^{\prime} \mathrm{E}$ and latitudes $6^{\circ}-6^{\circ} 45^{\prime} \mathrm{N}$, was mapped out in to five (5) subareas of Agbor Obi, Boji-Boji Agbor, Boji-Boji Owa, Alihame, and Owa Alero (see Figure 1).

The latter two areas (Alihame and Owa Alero) being classified as suburban towns for the purpose of this exercise on the basis of socio-economic stratification and population density. The geology of the area is mainly of 
Table 1 Summary of Nigerian and some international guideline values for drinking water samples

\begin{tabular}{|c|c|c|c|c|}
\hline Parameter (element/substance) & $\begin{array}{l}\text { Nigerian guideline value } \\
\text { (mg/L) }\end{array}$ & $\begin{array}{l}\text { WHO guideline value } \\
\text { (mg/L) }\end{array}$ & $\begin{array}{l}\text { USEPA guideline value } \\
\text { (mg/L) }\end{array}$ & $\begin{array}{l}\text { EU guideline value } \\
\text { (mg/L) }\end{array}$ \\
\hline Arsenic (As) & 0.01 & 0.01 & 0.01 & 0.01 \\
\hline Barium $(\mathrm{Ba})$ & 0.7 & 0.7 & 2.0 & NA \\
\hline Cadmium (Cd) & 0.003 & 0.003 & 0.005 & 0.005 \\
\hline Chlorine $\left(\mathrm{Cl}^{-}\right)$ & 250 & 250 & 250 & 400 \\
\hline Chromium $\left(\mathrm{Cr}^{6+}\right)$ & 0.05 & 0.05 & 0.1 & 0.05 \\
\hline Chemical Oxygen Demand & NA & NA & NA & NA \\
\hline Conductivity $(\mu \mathrm{S} / \mathrm{cm})$ & 1000 & NA & NA & NA \\
\hline Cyanide $\left(\mathrm{CN}^{-}\right)$ & 0.01 & 0.07 & 0.2 & 0.05 \\
\hline Hardness $\left(\mathrm{as} \mathrm{CaCO}_{3}\right)$ & 150 & 180 & NA & NA \\
\hline Iron $\left(\mathrm{Fe}^{+2}\right)$ & 0.3 & 0.3 & 0.3 & 0.2 \\
\hline Manganese $\left(\mathrm{Mn}^{2+}\right)$ & 0.2 & 0.4 & 0.05 & 0.001 \\
\hline Mercury (Hg) & 0.001 & 0.006 & 0.002 & 0.001 \\
\hline Nitrate & 50 & 50 & 10 & 50 \\
\hline $\mathrm{Ph}$ & $6.5-8.5$ & $6.5-8.0$ & $6.5-8.5$ & $5.5-9.5$ \\
\hline Phosphate $\left(\mathrm{PO}_{4}^{3-}\right)$ & NA & NA & NA & NA \\
\hline Sodium (Na) & 200 & 200 & NA & 150 \\
\hline Sulphate $\left(\mathrm{SO}_{4}^{2-}\right)$ & 100 & 250 & 250 & 250 \\
\hline Total Dissolved Solids & 500 & NA & NA & NA \\
\hline Zinc (Zn) & 3.0 & 3.0 & 5.0 & NA \\
\hline
\end{tabular}

NA No guideline available.

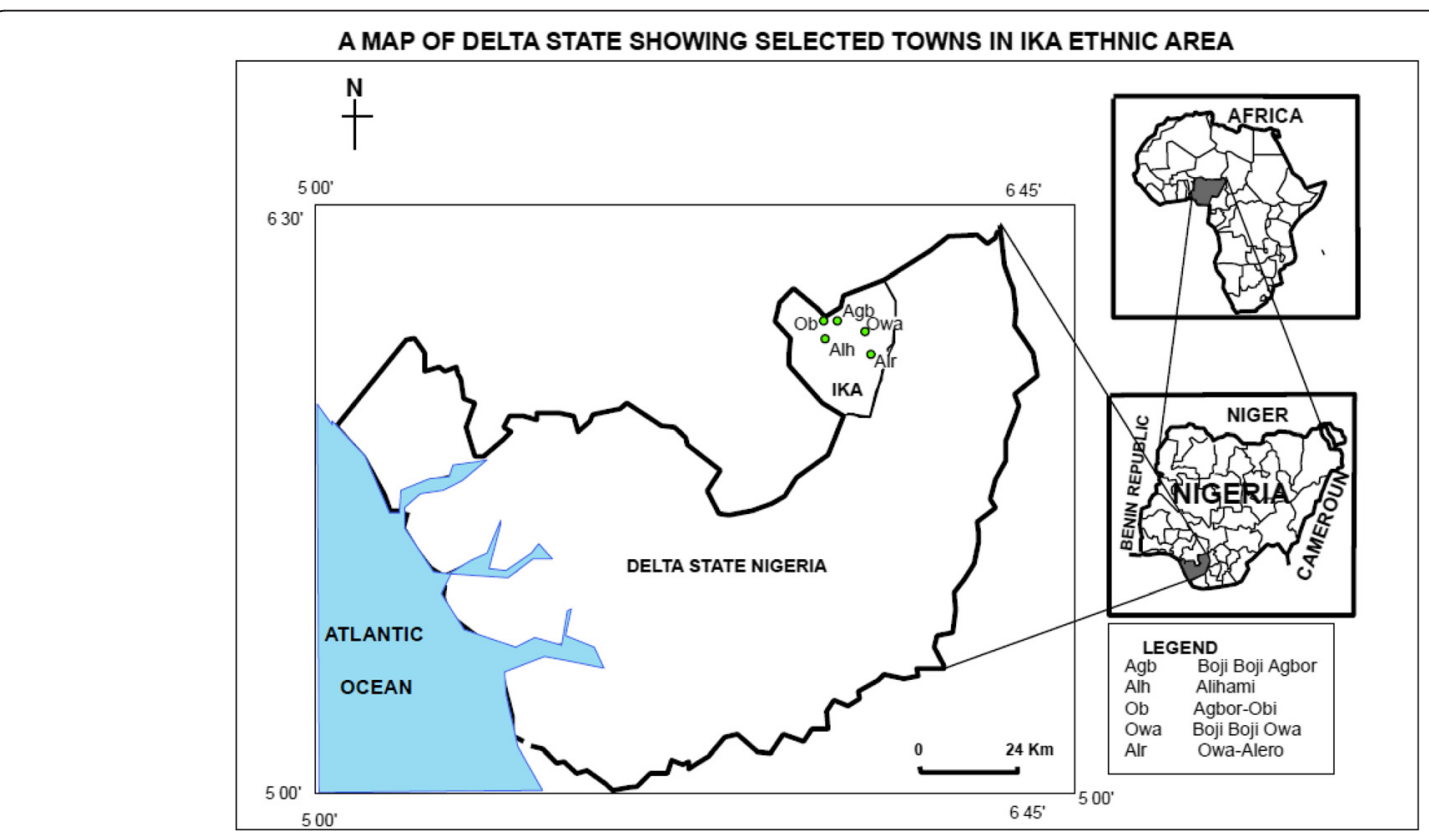

Figure 1 Map of Delta State Nigeria showing sample sites. Source: Department of Land Information Systems, Ministry of Lands Surveys and Urban Development, Asaba Delta State. 
the recent tertiary sedimentary sandstone with fine to coarse reddish (iron, haematite) sediments in texture giving it a porous nature, with the Bini formation as a typical example. This indicates a lee way for easy passage of leachate (like iron) in to the groundwater in the underlying aquifer.

The climate of the study area exhibits the characteristics of a sub-equatorial climate with an annual mean air temperature of $27.0{ }^{\circ} \mathrm{C}$ (Odjugo 2008). The rainfall pattern is that of double peaks or maximal with mean annual rainfall of $2,255 \mathrm{~mm}$, while the mean relative humidity is $81 \%$, sunshine is $5.6 \mathrm{hr} /$ day and the soil type is red-yellow ferralsols (Avwunudiogba 2000).

\section{Experimental}

A total of 50 borehole water sources was sampled from these areas, with an average of about 12-15 per area for Agbor Obi, Boji-Boji Agbor and Owa areas, and five (5) for Owa Alero and Alihame communities on the basis of fewer wells per unit area. Samples were collected in clean new $300 \mathrm{ml}$ sterile bottles with corks (Burubai et al. 2007). Borehole water sample sites were randomly spaced and samples collected in sterile bottles filled to the brim, then preserved by cooling in dark ice bag (Tomar, 1999) before taken to the laboratory for analysis immediately after sampling without filtration and acidification (EPA 2000).

Analyses of samples were done in the laboratories of the College of Education Agbor and at a private laboratory. At the laboratory, the samples were carefully transferred in to a clean $4 \mathrm{~L}$ container and a composite sample (Patil 2012) was thus formed per sample subarea. An average of 12-15 individual borehole water samples were combined in to a composite per sub-area in the three main sub-areas. One sub-area at a time was sampled. These composites were analyzed each in triplicates along with a blank (distilled deionized water, DDW) using Solar Unicam Atomic Absorption Spectrophotometer (United Nations International Children's Emergency Fund UNICEF 2008) model 969 series, with a detection limit of $0.0001 \mathrm{mg} / \mathrm{L}$ and limit of quantification of $0.0003 \mathrm{mg} / \mathrm{L}$ respectively. Methods were consistent with APHA (2005) and (United Nations
International Children's Emergency Fund UNICEF 2008).

All samples were collected in the mornings in the month of August, 2013 during the wet season, with rainfall at its peak in the months of July/August in southern Nigeria (UNOCHA 2013).

Typical water parameters like $\mathrm{pH}$, total dissolved solids, turbidity, conductivity, and cyanide and other anions and cations together with some microbiological parameters were all studied, some of these are already published (Oyem et al., 2014).

\section{Results and discussion}

The results of selected heavy metals in groundwater of the study area are displayed in Table 2. Generally, the studied metal ions concentration were below WHO guideline values.

\section{Iron}

Iron is a secondary priority chemical contaminant (United Nations International Children's Emergency Fund UNICEF 2008). The concentration of iron from the sampled areas show very distinctly that the largest concentration of iron $(0.13 \mathrm{mg} / \mathrm{L})$ representing $26.5 \%$ (Table 3) was obtained at Boji-Boji Agbor sample subarea, this is typical of the area bearing in mind that the commercial activities of automobile mechanics and iron/ metal works artisans, and carcasses of abandoned and unserviceable cars are strewn about.

Percentage heavy metal detected is an expression of the concentration of these metals in a sample sub-area relative to the total concentration of the same metal in the entire study area in percentage term. Boji Boji Agbor is highest in concentration of Fe (26.50\%). Alihame was next with an iron concentration of $0.11 \mathrm{mg} / \mathrm{L}(22.5 \%)$ which is rather surprising giving its rural setting. However, this may not be unconnected with the hydrogeological nature of the area. Owa Alero $(0.07 \mathrm{mg} / \mathrm{L})$ was the least Fe (14.3\%). In all, the study area was observed to have a mean iron concentration of $0.10 \mathrm{mg} / \mathrm{L}$. Iron is frequently found in groundwater due to large deposits in the earth's surface; however, a limit of $0-0.3 \mathrm{mg} / \mathrm{L}$ is acceptable (Edet et al. 2011).

Table 2 Presents the concentrations of selected heavy metals in the ground water of the study area

\begin{tabular}{lllllll}
\hline Sample Area & Fe $(\mathbf{m g} / \mathbf{L})$ & Mn $(\mathbf{m g} / \mathbf{L})$ & Zn $(\mathbf{m g} / \mathbf{L})$ & Cr $(\mathbf{m g} / \mathbf{L})$ & As $(\mathbf{m g} / \mathbf{L})$ & Cd $(\mathbf{m g} / \mathbf{L})$ \\
\hline Agbor Obi & 0.090 & 0.007 & 0.019 & $\mathrm{BDL}$ & $\mathrm{BDL}$ & $\mathrm{BDL}$ \\
Boji-Boji Agbor & 0.130 & 0.011 & 0.028 & $\mathrm{BDL}$ & $\mathrm{BDL}$ & $\mathrm{BDL}$ \\
Boji-Boji Owa & 0.090 & 0.018 & 0.010 & $\mathrm{BDL}$ & $\mathrm{BDL}$ & $\mathrm{BDL}$ \\
Owa Alero & 0.070 & 0.009 & 0.015 & $\mathrm{BDL}$ & $\mathrm{BDL}$ & $\mathrm{BDL}$ \\
Alihame & 0.110 & 0.013 & 0.006 & $\mathrm{BDL}$ & $\mathrm{BDL}$ & $\mathrm{BDL}$ \\
Mean & $\mathbf{0 . 1 0 0}$ & $\mathbf{0 . 0 1 0}$ & $\mathbf{0 . 0 2 0}$ & $\mathrm{BDL}$ & $\mathrm{BDL}$ & $\mathrm{BDL}$ \\
\hline
\end{tabular}

$B D L$ Below detection limit $(<0.0001 \mathrm{mg} / \mathrm{L})$. 
Table 3 Comparative analysis of iron contents of individual sample sub-areas relative to WHO maximum contaminant level

\begin{tabular}{|c|c|c|c|c|c|}
\hline & Agbor Obi & Boji-Boji Agbor & Boji-Boji Owa & Owa Alero & Alihame \\
\hline Fe detected (\%) & 18.4 & 26.5 & 18.4 & 14.3 & 22.5 \\
\hline Minimum conc. Detected (mg/L) & 0.08 & 0.12 & 0.08 & 0.06 & 0.10 \\
\hline Maximum conc. Detected (mg/L) & 0.10 & 0.14 & 0.10 & 0.08 & 0.12 \\
\hline WHO Maximum Contaminant Level (MCL) (mg/L) & 0.30 & 0.30 & 0.30 & 0.30 & 0.30 \\
\hline Number above MCL & 0 & 0 & 0 & 0 & 0 \\
\hline
\end{tabular}

The levels of Fe in groundwater can be increased by dissolution of ferrous borehole and hand pump components (Lenntech 2009). Results of Fe and Mn reported in this study generally agree with those reported by Edet et al. (2011).

The use of groundwater for drinking is in many cases limited by the presence of dissolved iron, and to a lesser extent, manganese. These give the water an unpleasant metallic taste, and stain food, sanitary wares and laundry (United Nations International Children's Emergency Fund UNICEF 2008). Therefore the results obtained for the iron content of the groundwater in this study are rather encouraging, and suggests portable water quality with reference to the metals under study; especially as values recorded are all far below the Nigerian (Nigerian Industrial Standard 2007), WHO, United States Environmental Protection Agency (USEPA) and European Union (EU) guideline values.

\section{Manganese}

Manganese like iron is a secondary priority chemical contaminant. The values derived for manganese are expressed in Table 2 as well. Boji-Boji Owa recorded the highest manganese value of $0.018 \mathrm{mg} / \mathrm{L}$ representing 31.0\% (Table 4).

This again is expected in view of the economic density of automobile and allied metal activities in the Boji-Boji area. $0.013 \mathrm{mg} / \mathrm{L}(22.4 \%)$ was the second highest value obtained for Alihame. Again, Alihame showing high metal ion content with reference to Fe and Mn indicating a natural hydrogeologic factor rather than anthropogenic. Boji-Boji Agbor posted a significant value when compared with those of Owa Alero and Agbor Obi (with the least value of all sampled areas). However the entire study area reported an average manganese value of
$0.010 \mathrm{mg} / \mathrm{L}$. This again is far lower than the guideline value recommended by Nigerian, WHO, EU, and USEPA, indicating yet again palatability quality wise, since it is one of the secondary priority chemical contaminants, and also responsible in this case also for water being rejected for aesthetic purposes (United Nations International Children's Emergency Fund UNICEF 2008).

\section{Zinc}

Zinc was observed in all the sub-areas of the study as can be seen in Table 5. However, an average concentration of $0.02 \mathrm{mg} / \mathrm{L}$ was determined for the area under study. $0.028 \mathrm{mg} / \mathrm{L}$ obtained in Boji Boji Agbor was the highest value noted in the entire sampled areas, representing $36.0 \%$ (Table 5). All others were below $0.020 \mathrm{mg} / \mathrm{L}(0.19,0.015,0.010$, and $0.006 \mathrm{mg} / \mathrm{L})$. The result obtained in Boji Boji Agbor could be attributed to the fact that zinc being a constituent of roofing sheets, has been washed down by rainfall into the soil before ending up in the underground water by leaching over decades of time in these semi-urban areas. Alihame recorded near zero concentration. Nonetheless, it is speculated that the zinc content of this study area could be attributed to natural causes rather than human activities. Zinc imparts an undesirable astringent taste to water at concentrations exceeding $3 \mathrm{mg} / \mathrm{L}$ (as $\mathrm{ZnSO}_{4}$ ). However, drinking water seldom contains zinc above $0.1 \mathrm{mg} / \mathrm{L}$. Pipe line water supply with galvanized plumbing material records higher levels of zinc (World Health Organization WHO 2010). More so, an average zinc value of $0.02 \mathrm{mg} / \mathrm{L}$ observed for the study area is acceptable, since both the Nigerian and WHO guideline is set at $3.0 \mathrm{mg} / \mathrm{L}$ for zinc in drinking water.

Table 4 Comparative analysis of manganese contents of individual sample sites in the study area

\begin{tabular}{|c|c|c|c|c|c|}
\hline & Agbor Obi & Boji-Boji Agbor & Boji-Boji Owa & Owa Alero & Alihame \\
\hline Mn detected (\%) & 12.1 & 19.0 & 31.0 & 15.5 & 22.4 \\
\hline Minimum conc. Detected (mg/L) & 0.006 & 0.008 & 0.016 & 0.008 & 0.012 \\
\hline Maximum conc. Detected (mg/L) & 0.008 & 0.015 & 0.020 & 0.010 & 0.014 \\
\hline WHO Maximum Contaminant Level (MCL) (mg/L) & 0.400 & 0.400 & 0.400 & 0.400 & 0.400 \\
\hline Number above MCL & 0 & 0 & 0 & 0 & 0 \\
\hline
\end{tabular}


Table 5 Comparative analysis of zinc contents of the study area

\begin{tabular}{|c|c|c|c|c|c|}
\hline & Agbor Obi & Boji-Boji Agbor & Boji-Boji Owa & Owa Alero & Alihame \\
\hline Zn detected (\%) & 24.4 & 36.0 & 12.8 & 19.2 & 7.7 \\
\hline Minimum conc. Detected (mg/L) & 0.017 & 0.027 & 0.009 & 0.013 & 0.005 \\
\hline Maximum conc. Detected (mg/L) & 0.019 & 0.029 & 0.012 & 0.017 & 0.008 \\
\hline WHO Maximum Contaminant Level (MCL) (mg/L) & 3.000 & 3.000 & 3.000 & 3.000 & 3.000 \\
\hline Number above $\mathrm{MCL}$ & 0 & 0 & 0 & 0 & 0 \\
\hline
\end{tabular}

\section{Arsenic, cadmium and chromium}

Arsenic, cadmium, and chromium were all below detection limit in the groundwater of the study area. This implies that the groundwater in the study had no traces of the metal ions being mentioned, or that their concentrations were just too low to be detected by the instrument of analysis. This is good news, since cadmium and chromium might be considered a threat, and certainly arsenic in drinking water is a global threat to health (United Nations International Children's Emergency Fund UNICEF 2008; World Health Organization WHO 2010). None of these metals were detected in water from all five sampled areas collected for analysis.

\section{Chromium}

Chromium occurs in several forms in the environment, most of which are $\mathrm{Cr}^{3+}$ and $\mathrm{Cr}^{6+}$ with varying health importance; but drinking water standards are typically made for total chromium (United Nations International Children's Emergency Fund UNICEF 2008). Concentrations of chromium in natural water is usually low, however, elevated concentrations result from mining and industrial processes (Momodu and Anyakora 2010). Chromium (VI) has severe health impact (United Nations International Children's Emergency Fund UNICEF 2008) when inhaled. However, there's no evidence of its carcinogenicity when taken orally (Flegal and Last 2001). Hence its health impact is still a subject of controversy. A guideline value of $0.05 \mathrm{mg} / \mathrm{L}$ is given to chromium by the WHO.

The non-detect result for chromium in this study is an indication and likely confirmation of the absence of mining and other forms of industrial activities.

\section{Cadmium}

Cadmium metal is used in steel, plastic, and battery industries (World Health Organization WHO 2010). Its presence in drinking water could be as a result of impurities from galvanized zinc pipes and solder, together with other metal fittings. Cadmium accumulates in the kidney being its target organ of toxicity (World Health Organization WHO 2010). Cadmium is potentially carcinogenic in humans; it is the cause of itai itai disease observed in Japan due to excess intake (Lauwerys 1979). It has long biological half-life of 10-35 years in humans
(Orisakwe, et al. 2006) leading to chronic effects as a result of accumulation in the liver and renal cortex (Hammer and Hammer 2004). Although there is no evidence of its carcinogenicity, the WHO has a guideline value for Cadmium of $0.003 \mathrm{mg} / \mathrm{L}$.

\section{Arsenic}

Arsenic in water is mostly present as arsenate (5+), but in anaerobic conditions, it is likely present as arsenite (3 +) (World Health Organization WHO 2010). Arsenic in drinking water is a global threat to health (United Nations International Children's Emergency Fund UNICEF 2008; World Health Organization WHO 2010). It is considered by some researchers to have more serious health repercussions than any other environmental contaminant (Smith and Steinmaus 2007). Signs of chronic exposure to arsenic, including dermal lesions such as hyper-and hypo-pigmentation, peripheral neuropathy, skin cancer, bladder and lung cancers and peripheral vascular disease, have been observed in populations ingesting arsenic-contaminated drinking water (World Health Organization WHO 2010); with both $\mathrm{As}^{3+}$ and $\mathrm{As}^{5+}$ rapidly and extensively absorbed from the gastrointestinal tract. Although arsenic contaminations occur in surface water, it is more common in ground water (United Nations International Children's Emergency Fund UNICEF 2008), where arsenic remain tightly bound to sediments under geochemical conditions, and dissolved levels remain very low until released by the parent rock. There is no effective treatment for chronic arsenic poisoning, except for switching to arsenic-free drinking water source (United Nations International Children's Emergency Fund UNICEF 2008). A guideline value of $0.01 \mathrm{mg} / \mathrm{L}$ is given to it by the (World Health Organization WHO 2010).

Table 6, gives a picture of the total detected heavy metal content of the individual study sub-areas in percentage. Noticeably, that the highest concentration $(\sim 27$ per cent) of heavy metals in the groundwater is concentrated in the Boji-Boji Agbor area. Both Boji-Boji Agbor and Owa areas being the centre of town and hub of commercial and sociological activities has a high combined heavy metals capacity of close to 50 percent of the total study area. However, a striking report of note is the total heavy metals content determined for Alihame. 
Table 6 Iron, manganese, and zinc metals combined distribution in groundwater of the individual sample sites in the study area

\begin{tabular}{llllll}
\hline Sample site & Fe $(\mathbf{m g} / \mathbf{L})$ & Mn $(\mathbf{m g} / \mathbf{L})$ & Zn $(\mathbf{m g} / \mathbf{L})$ & Total $(\mathbf{m g} / \mathbf{L})$ & Percentage $(\%)$ \\
\hline Agbor Obi & 0.090 & 0.007 & 0.019 & 0.116 & 18.53 \\
Boji-Boji Agbor & 0.130 & 0.011 & 0.028 & 0.169 & 26.99 \\
Boji Boji Owa & 0.090 & 0.018 & 0.010 & 0.118 & 18.85 \\
Owa Alero & 0.070 & 0.009 & 0.015 & 0.094 & 15.02 \\
Alihame & 0.110 & 0.013 & 0.006 & 0.129 & 20.60 \\
& & & & Total $=0.626 \mathrm{mg} / \mathrm{L}$ & \\
\hline
\end{tabular}

Although, considered a suburban area, it is nonetheless a budding commercial hub and residential area, hosting students of the College of Education, Agbor, and State School of Nursing, Agbor, as well as staff of these institutions, civil servants and indigenous settlers.

Analysis of variance (ANOVA) is designed for simultaneous testing of equality of three or more populations of independent groups to determine if each group mean is identical assuming each has a normal distribution around its mean (Helsel and Hirsch 2002). Therefore in this study, to ascertain if data from the sampled subareas are identical or significantly different, we employed the use of a single factor ANOVA tool (Helsel and Hirsch 2002; Muhammad et al. 2011).

Table 7, presents a one-way analysis of variance (ANOVA) statistical comparison of selected heavy metal contaminants from the different sample subareas. Results indicate that the groundwater from individual sample sub-areas are individually different from each other and are thus not the same. This obviously shows that different sites contribute differently to the mean heavy metal concentrations of the water in the study areas' aquifer. Variations in this regard probably arise from changes along the groundwater flow path, and slight variations in net effect of the $\mathrm{pH}$ dependent processes of minerals dissolution and precipitations (hydrogeology).

\section{Chronic daily intake}

Health risks associated with ingestion of heavy metals in the groundwater of this study area are assessed using the chronic daily intake and hazard index parameters. The CDI through water ingestion was calculated according to the modified equation from USEPA (1992) and Chrostowski (1994):

$$
C D I=C \times D I / B W
$$

Where, C, DI, and BW represent the concentration of heavy metals in water $(\mu \mathrm{g} / \mathrm{L})$, average daily intake rate $(2 \mathrm{~L} /$ day $)$ and body weight $(72 \mathrm{~kg})$, respectively (USEPA 2005).

Results suggest that groundwater in the study area contains some dissolved heavy metals. CDI values obtained ranged from 0.02 to 0.13 for $\mathrm{Fe}, 0.0002$ to 0.0005 for $\mathrm{Mn}$, and 0.0002 to 0.0008 for $\mathrm{Zn}$. Therefore, the order of heavy metal mean toxicity for the groundwater of the study area is $\mathrm{Fe}>\mathrm{Mn}>\mathrm{Zn}$ respectively; with $\mathrm{Cd}$, $\mathrm{Cr}$, and As none detected. These CDI values, however, give an indication of possible toxicity of these heavy metals found in the aquifer of the area. Since the CDI is below the reference dose, (RfD) values (USEPA 2005), it is assumed that the risk of consuming water with this heavy metals concentration is negligible for all members of an exposed population.

Table 7 One-way ANOVA comparison of detected heavy metal contaminants in the study area

\begin{tabular}{|c|c|c|c|c|c|c|}
\hline Metals & & Sum of squares & $\mathrm{df}^{\mathrm{a}}$ & Mean Square & $F^{b}$ & P-value \\
\hline \multirow[t]{3}{*}{$\mathrm{Fe}$} & Between group & 0.0063 & 2 & 0.0032 & 38.4 & 0.00001 \\
\hline & Within group & 0.0010 & 12 & 0.000083 & & \\
\hline & Groups total & 0.0073 & 14 & & & \\
\hline \multirow[t]{3}{*}{$\mathrm{Mn}$} & Between group & 0.000252 & 2 & 0.000126 & 16.0 & 0.0004 \\
\hline & Within group & 0.000100 & 12 & 0.000008 & & \\
\hline & Groups total & 0.000352 & 14 & & & \\
\hline \multirow[t]{3}{*}{$\mathrm{Zn}$} & Between group & 0.001158 & 2 & 0.000599 & 217.8 & 0.0 \\
\hline & Within group & 0.000033 & 12 & 0.00000275 & & \\
\hline & Groups total & 0.001191 & 14 & & & \\
\hline
\end{tabular}

$\mathrm{P}<0.05{ }^{\mathrm{a}}$ Degree of freedom ${ }^{\mathrm{b}}$ Factor. 


\section{Hazard quotient}

The hazard quotient (HQ) for non-carcinogenic risk can be calculated from equation:

$$
H Q=C D I / R f D
$$

(Gerba 2001, and USEPA 1999)

Table 8 also gives a summary of the hazard index on the health of the people of this area through regular consumption of groundwater. The mean hazard index values for the studied heavy metals ranged from 0.001 to 0.006 for $\mathrm{Fe}, 0.001$ to 0.004 for $\mathrm{Mn}$, and 0.001 to 0.003 for $\mathrm{Zn}$ respectively, the order of toxicity being $\mathrm{Fe}>\mathrm{Mn}$ $>\mathrm{Zn}$. Meanwhile, the hazard index calculated from the sum of the mean hazard quotients of the contaminants (eqn 3):

$$
\text { Hazard Index mean }=\mathrm{HQ}_{\mathrm{Fe}}+\mathrm{HQ}_{\mathrm{Mn}}+\mathrm{HQ}_{\mathrm{Zn}}
$$

(United States Environmental Protection Agency and US 2006)

$$
\begin{aligned}
& =0.004+0.002+0.002 \\
& \text { Hazard Index }_{\text {mean }}=\mathbf{0 . 0 0 8}(\mathbf{0 . 0 1} \text { approx. })
\end{aligned}
$$

Therefore, since the hazard index is less than 1.0 (Khan et al. 2008, Krishna and Mohan 2013), the water is confirmed as being safe with reference to the studied parameters and results reported.

\section{Correlational analysis}

Result of the correlational matrix as displayed in Table 9 did not reveal any strong or significant inter-metal relationships in the groundwater under study; hence it does not provide enough information on metal sources and pathways (Manta et al. 2002).

\section{Conclusion}

This study looked in to the groundwater aquifer quality at the centre of Ika land with specific reference to the Boji-Boji Agbor/Owa metropolis and its immediate suburbs Alihame and Owa Alero.
Table 9 Correlation matrix of selected heavy metals in groundwater of the study area

\begin{tabular}{llll}
\hline Correlations & & & \\
& Fe & Mn & Zn \\
\hline Fe & 1 & 0.146 & 0.407 \\
Mn & 0.146 & 1 & -0.493 \\
Zn & 0.407 & -0.493 & 1 \\
\hline
\end{tabular}

Of the heavy metal ions studied, arsenic, cadmium, and chromium were below detection limit in all the sample sub-areas, however, iron, manganese, and zinc were all detected. Boji-Boji Agbor posted the highest iron value of all, Agbor Obi and Boji-Boji Owa had the least. Manganese is highest in Boji-Boji Owa, and least in Agbor Obi. Again, Boji-Boji Agbor and Alihame recorded the highest and least values of zinc respectively. By implication therefore, and apart from a few rather high metal ion values, there is an obvious description of high heavy metal load in the city centre more than in the suburban remote areas. Indeed this gives credence to the anthropogenic theory of human activities and socioeconomic effect having a bearing on groundwater quality.

There are no significant inter-metal relationships from the correlational matrix analysis; hence, not enough information on hydro-geologic heavy metal ions sources and pathways are available for the study area.

Inhabitants of this area are under no immediate or remote health threat from the consumption of this water resource. More so, with the results of the analyses of the chronic daily intake ( $2 \mathrm{~L}$ per day at $72 \mathrm{Kg}$ body weight) and the hazard index values pointing very strongly on the wholesomeness of the groundwater relative to heavy metal and arsenic contents, with any short and longterm health implications very unlikely and far-fetched.

It becomes very incisive therefore, from the results of these three heavy metal types (chromium, arsenic, and cadmium) that the people of this study area are rather fortunate. As the below detection limit results obtained is a pointer to the wholesomeness of the groundwater aquifer under which they reside. In addition, evidence

Table 8 Chronic daily intake and Hazard quotient indices with Reference dose for studied heavy metals

\begin{tabular}{lllll}
\hline Heavy metals & Statistics & CDI $\mathbf{~ m g / k g - d a y ~}$ & HQ & RfD $\mathbf{~ m} / \mathbf{k g}$-day $^{\mathbf{a}}$ \\
\hline $\mathrm{Fe}$ & Min 0.07 Max 0.13 Mean 0.10 SD 0.023 & 0.0020 .0040 .0030 .0006 & 0.0030 .0060 .0040 .0009 & 0.7 \\
$\mathrm{Mn}$ & Min 0.007 Max 0.018 Mean 0.010 SD 0.005 & 0.00020 .00050 .00030 .0004 & 0.0140 .0040 .0020 .003 & 0.14 \\
$\mathrm{Zn}$ & Min 0.006 Max 0.028 Mean 0.020 SD 0.009 & 0.00020 .00080 .00060 .0003 & 0.00070 .0030 .0020 .001 & 0.3 \\
$\mathrm{Cd}$ & $\mathrm{BDL}$ & $\mathrm{BDL}$ & $\mathrm{BDL}$ & 0.0005 \\
$\mathrm{Cr}$ & $\mathrm{BDL}$ & $\mathrm{BDL}$ & $\mathrm{BDL}$ & 0.015 \\
$\mathrm{As}$ & $\mathrm{BDL}$ & $\mathrm{BDL}$ & $\mathrm{BDL}$ & 0.0003 \\
\hline
\end{tabular}


suggests that levels of arsenic in ground water aquifers in many parts of the world are acceptably below the WHO drinking water guideline (United Nations Environmental Programme Global Environmental Monitoring System and UNEP 2007).

From these results therefore and the parameters studied, it is fitting to conclude and report that the ground water aquifer of Agbor and Owa area generally meet national and international acceptable standards and is therefore adjudged as being safe for drinking with regards to these heavy metals. However, its use for other sundry domestic and agricultural purposes will require further analyses to decipher. We recommend an analysis of individual boreholes to determine any localized areas of poor water quality.

\section{Competing interests}

The authors declare that they have no competing interests.

\section{Authors' contributions}

$\mathrm{HH}$ and IM planned and carried out the experiments, $\mathrm{HH}$ analyzed the data, and drafted the manuscript. All authors read and approved the final manuscript.

\section{Acknowledgement}

We wish to appreciate the Tertiary Education Trust Fund for this wonderful privilege and opportunity to further of our research endeavours. Appreciation also goes to the Management of the College of Education, Agbor under whose auspices this Grant was offered for the enabling environment for academic growth and development. We also wish to thank individuals and research outfits whose experiences and resources were consulted in this exercise.

\section{Author details}

'Department of Integrated Science, College of Education, Agbor, PMB 2090, Delta State, Nigeria. ${ }^{2}$ School of Chemistry, Newcastle University, Newcastle, NE1 7RU, United Kingdom. ${ }^{3}$ Department of Microbiology, University of Benin, Benin City, Edo State, Nigeria. ${ }^{4}$ Department of Marine Sciences, Faculty of Science, University of Lagos, Akoka-Yaba, Lagos, Nigeria.

Received: 24 October 2014 Accepted: 30 January 2015

Published online: 01 March 2015

\section{References}

Ahaneku IE, Adeoye PA (2014) Impact of pit laterines on groundwater quality of Fokoslum, Ibadan, Southwestern Nigeria. Brit J of Appl Sci and Tech 4(3):440-449

APHA (2005) Standard Methods for Water and Wastewater, 21st edn. American Public Health Association, Washington, D.C

Avwunudiogba A (2000) A comparative analysis of soil and nutrient losses on maize plant with different tillage practices in Ikpoba River basin of south-western Nigeria. Niger Geogrhc J New Series 3(4):199-208

Bresline E (2007) Sustainable water supply in developing countries. Geolgcl Socty of Amer. Paper No. 1: 194

Burubai W, Akor AJ, Lilly MT (2007) Performance evaluation of septic system for high water-table areas. Ameri-Euroasian J Sci Res 2(2):112-116

Chrostowski PC (1994) Exposure assessment principles. In: Patrick DR (ed) Toxic Air Pollution Handbook. Van Nostrand Reinhold, New York

Edet A, Nganje TN, Ukong AJ, Ekwere AS (2011) Groundwater chemistry and quality of Nigeria: a status review. Afri J Environ Sci Tech 5(13):1152-1169

EPA (2000) A guide to the sampling and analysis of waters, wastewaters, soils and wastes. Environment Protection Authority State Government of Victoria. http://www.epa.vic.gov.au

Flegal R, Last J (2001) Scientific review of toxicological and human health issues related to the development of public health goal for chromium (vi). Chromate toxicity review committee, Sacramento, Available via: http://www oehha.ca.gov/public_info/facts/pdf/CrPanelRptFinal901.pdf
Ganesh K, Hedge KYS (1995) Quality of lenetic waters of Dharwad district in North Karnataka. J Environ Health 7(1):52-56

Gerba CP (2001) Risk assessment. In: Lorna F, Jamie B (eds) Water Quality: Guidelines, Standards and Health. IWA publishing, UK, London

Hammer MJ, Hammer MJ Jr (2004) Water Quality. In: Water and Waste Water Technology, 5th edn. Prentice-hall, New Jersey, pp 139-159

Helsel DR, Hirsch RM (2002) Statistical methods in water resources technique of water resources investigation. Survey, Geological. Book 4, Chapter A3, Pp 522. available at: http://water.usgs.gov/pubs/twri/twri4a3/

Idoko OM (2010) Seasonal variation in Iron in rural groundwater of Benue State, Middle Belt, Nigeria. Pakist J Nutrin 9(9):892-895

Khan S, Cao Q, Zheng YM, Huang YZ, Zhu YG (2008) Health risk of heavy metals in contaminated soils and food crops irrigated with wastewater in Beijing China. Environ Pollut 152:686-692

Krishna AK, Mohan KR (2013) Risk assessment of heavy metals and their source distribution in waters of a contaminated industrial site. Environ Sci Pollut Res 21:3653-3669

Lashkaripour GR, Ghafoori M (2011) The effects of water table decline on the groundwater quality in aquifer of Torbat Jam Plain, Northeast Iran. Internl J Emerg Sci 1(2):153-163

Lauwerys RR (1979) Health effects of Cadmium. In: Di Ferrante E (ed) Trace metal: Exposure and Health Effects. Pergamon Press, England, Oxford, pp 43-64

Lenntech (2009) Iron in groundwater. Lenntech water treatment and purification holding B. V, Rotterdamseweg, Netherlands

MacDonald A M, \& Calow RC (2009) Developing groundwater for secure rural water supplies in Africa. Desalination. doi:10.1016/j.desal.2008.05.100

Majuru B, Michael MM, Jagals P, Hunter PR (2011) Health impact of small-community water supply reliability. Internl J Hygi Environl Health 214(2):162-166

Manta DS, Angelone M, Bellanca A, Neri R, Sprovieri M (2002) Heavy metals in urban soils: a case study from the city of Palermo (Sicily), Italy. Sci Total Environt 300:229-243

Momodu MA, Anyakora CA (2010) Heavy metal contamination of groundwater: the Surulere case study. Res J Environtal Earth Scis 2(1):39-43

Muhammad S, Shah MT, Khan S (2011) Health risk assessment of heavy metals and their source apportionment in drinking water of Kohistan region, northern Pakistan. Microchem J 98:334-343

National Academy of Science NAS (2009) National Academy of Science: Overview-Safe Drinking Water is Essential. The National Academies Press, Washington, D.C

Nigerian Industrial Standard NIS (2007) Nigerian Standard for drinking water quality. Standards Organization of Nigeria, Abuja

Odjugo PAO (2008) The effect of tillage systems and mulching on soil microclimate, growth and yield of yellow yam (Dioscora cayenensis) in Midwestern Nigeria. Afri J Biotech 24:4500-4507

Ohwoghere AO (2012) Heavy metals distribution in degraded land forms in Delta State of the Niger Delta. J Geolgy Min Res 4(3):43-50

Orisakwe OE, Igwilo OI, Afonne OJ, Maduabuchi JU, Obi E, Nduka JC (2006) Heavy metal hazards of sachet water in Nigeria. Arch Environ Occup Health 61(5):209-213

Oyem, H. H., Oyem, I. M., and Ezenweali, D. (2014). Temperature, pH, Electrical Conductivity, Total Dissolved Solids and Chemical Oxygen Demand of Groundwater in Boji-BojiAgbor/Owa Area and Immediate Suburbs. Resrch Jourl of Environtal Science ISSN 1819-3412/ DOI: 103923/rjes.2014

Patil GP (2012) Composite sampling. In: El-Shaarawi AH, Piegorsch WW (eds) Encyclopedia of Environmetrics, vol 1 (1). John Wiley \& Sons, Ltd, ChiChester, pp 387-391

Ramesh K, Elango L (2014) Impact of groundwater quality from industrial East Coastal Town, Southern India. Intern J Eng Res Appli 4(1):346-354

Smith A, Steinmaus C (2007) High concentrations of arsenic in drinking water results in the highest known increases in mortality attributable to any environmental exposure. In: Paper presented at the "Arsenic in drinking water a global threat to health" sessions of the Royal Geographic Society Annual Conference, August 2007. Available at http://www.rgs.org

Tomar M (1999) Quality Assessment of Water and Wastewater. Lewis Publishers CRC press, Florida, USA

Tularam GA, Krishna A (2009) Long term consequences of groundwater pumping in Australia: a review of impacts around the globe. J of Sci in Environtl Sanitation 4(2):151-166

United Nations Department of Economics and Social Affairs, UNDESA (2001). Water quality. International decade for action 'water for life' 2005-2015. Retrieved from: http://www.un.org/waterforlifedecade/quality.shtml 
United Nations Environmental Programme Global Environmental Monitoring System, UNEP GEMS (2007) Water quality outlook. Available at: http://www. gemswater.org/

United Nations International Children's Emergency Fund (UNICEF) (2008) Handbook on Water Quality. UNICEF, New York

United States Environmental Protection Agency, US EPA (2006) Drinking water contaminants. Washington DC. Availaible at: http://www.unep.org/ gemswater/AboutUs/GEMSWaterintheNews?tabid/78236/Default.aspx

UNOCHA (2013) Rainy Season Overview for West Africa and Central Africa. United Nations Office for the coordination of Humanitarian Affairs, New York

USEPA (1992) Guidelines for Exposure Assessment EPA/600/Z-92/001. Risk Assessment Forum, Washington, DC

USEPA (1999) Guidance for Performing Adequate Exposure and Risk Assessment Office of Pesticide Programs. United States Environmental Protection Agency, Washington, DC

USEPA (2005) Guidelines for Carcinogenic Risk Assessment. United States Environmental Protection Agency. Risk Assessment Forum, Washington, DC World Health Organization WHO (1984) Guideline for Drinking Quality. Second Addendum to $3^{\text {rd }}$ Edition. World Health Organization, Geneva

World Health Organization WHO (2010) Water for Health, WHO Guidelines for Drinking-Water Quality. World Health Organization, Geneva

\section{Submit your manuscript to a SpringerOpen ${ }^{\circ}$ journal and benefit from:}

- Convenient online submission

- Rigorous peer review

- Immediate publication on acceptance

- Open access: articles freely available online

- High visibility within the field

- Retaining the copyright to your article 